\title{
Production and Identification of Biologically Active Peptides Derived from By-product of Hen Egg-Yolk Phospholipid Extraction
}

\author{
Ewelina Eckert ${ }^{1} \cdot$ Aleksandra Zambrowicz $^{2} \cdot$ Łukasz Bobak $^{2} \cdot$ Agnieszka Zabłocka $^{3}$ - Józefa Chrzanowska ${ }^{2}$. \\ Tadeusz Trziszka²
}

Accepted: 26 April 2018 / Published online: 28 April 2018

(c) The Author(s) 2018

\begin{abstract}
Biologically active peptides derived from food proteins have been increasingly popular due to their therapeutic properties. This paper attempts to utilize a by-product of phospholipid extraction from egg yolk as a source of peptides with antioxidant [radical scavenging capacity, $\mathrm{Fe}^{2+}$ chelating effect, reducing power (FRAP)] and ACE-inhibitory activity. In addition, in this research we analysed the ability to release bio-peptides of a non-commercial proteases obtained from Yarrowia lipolytica yeast. Yeast serine protease exert greater ability to evaluate antioxidant and ACE inhibitory activity than yeast aspartyl protease during degradation of protein by-product. Purification procedures including membrane filtration, gel filtration chromatography and reversed-phase high-performance liquid chromatography led to obtain a decapeptide QSLVSVPGMS with strong DPPH free radical scavenging and ACE inhibitory activities. A new application of the serine protease from $Y$. lipolytica yeast in the production of bioactive peptides from egg yolk protein by-product was demonstrated.
\end{abstract}

Keywords Egg yolk protein by-product $\cdot$ Hydrolysis $\cdot$ Antioxidant $\cdot$ Angiotensin ACE-inhibitory activity $\cdot$ Y. lipolytica

\section{Introduction}

Hen's egg is composed of various nutritive and preservative substances for a potential new life, which may be important for human health (Leśnierowski and Stangierski 2018). Egg yolk is an important and inexpensive supply of high bioactivity proteins. They can serve as precursors of bioactive peptides with different activities, such as antihypertensive, antihypercholesterolemic, antiproliferative, immunomodulation, antioxidant, opiate, antimicrobial, antidiabetic, antineuro-degenerative and mineral binding (Yu et al. 2018;

Aleksandra Zambrowicz

aleksandra.zambrowicz@upwr.edu.pl

1 Department of Agricultural, Food and Nutritional Science, University of Alberta, Edmonton AB T6G 2P5, Canada

2 Department of Animal Products Technology and Quality Management, Faculty of Biotechnology and Food Science, Wroclaw University of Environmental and Life Sciences, Chełmońskiego 37/41, 51-630 Wroclaw, Poland

3 Department of Signaling Proteins, Hirszfeld Institute of Immunology and Experimental Therapy, Polish Academy of Sciences, Rudolfa Weigla 12, 53-114 Wroclaw, Poland
Leśnierowski and; Stangierski 2018; Admassu et al. 2018; Zabłocka et al. 2018). Bioactive peptides are absorbed in the intestine and penetrate into the blood intact and exert systemic or local beneficial effects (Yu et al. 2018; Admassu et al. 2018; Zabłocka et al. 2018). Because of their characteristic biological activity as well as the high safety profile, they may have significant impact on development of natural drugs and nutraceuticals.

Egg yolk plasma contains a group of polypeptides, named yolkin, derived from CatD-mediated processing of vitellogenin during formulation of egg. Yolkin possesses immunomodulatory activity, and is a strong inducer of IL-1 $\beta$, IL-6, IL-10, TNF- $\alpha$ secretion in human whole blood (Polanowski et al. 2013; Zambrowicz et al. 2018). It also stimulates nitric oxide release from the macrophage cell line J774.2 and bone-marrow mouse macrophages (BMDM) (Zambrowicz et al. 2018). Yolkin plays a significant role in cognitive improvement, may mitigate the behavioral symptoms of aging and support cognitive learning and memory in rats (Lemieszewska et al. 2016). This neuroprotective effect is possibly mediated through reduced intracellular reactive oxygen species (ROS) production in PC12 cells and stimulation of brain-derived neurotrophic factor (BDNF) secretion 
by both neurons and also by human whole blood (Polanowski et al. 2013; Zambrowicz et al. 2018; Lemieszewska et al. 2016; Zabłocka et al. 2018).

Biologically active peptides are widely generated in vitro during controlled enzymatic hydrolysis of egg yolk proteins (YP) (Feng and Mine 2006; Katayama et al. 2006, 2007; Xu et al. 2007; Yousr et al. 2017). One of the most important protein precursor of bioactive peptides is phosvitin-the major glycophosphoprotein in egg yolk (Ishikawa et al. 2004). It was shown that phosphopeptides from phosvitin show strong antioxidant in vitro and in vivo activity against: linoleic acid autoxidation, DPPH free radical and oxidative stress in human intestinal epithelial cells (Shade and Chacana 2007; Duan et al. 2014). In addition, strong antioxidant properties of phosphopeptides affects other important attributes, including antimicrobial and anticancer activity (Katayama et al. 2006, 2007; Ishikawa et al. 2009). For example, strong antiproliferative properties have been proven for peptide KLSDW isolated from defatted egg yolk protein hydrolyzed with pepsin and pancreatin. It significantly inhibits cell viability of colon cancer cells (Caco-2) with no inhibitory effects on the viability of human colon epithelial normal cells (Yousr et al. 2017). Phosphopeptides from phosvitin shows also strong ability to enhance calcium bioavailability and inhibit the formation of insoluble calcium phosphates (Kozłowski et al. 1988; Shade and Chacana 2007).

High-density lipoproteins from egg yolk and their peptides demonstrated antiadhesive activities. It was shown that egg yolk supplementation inhibited colonization of some bacteria such as: Salmonella typhimurium, Campylobacter jejuni and E. coli O157:H7 in internal organs (Katayama et al. 2006). In addition, digestion of vitellenin - apoprotein of egg yolk lipovitellenin, with pronase gives Glycopeptide $\mathrm{A}$, which is characterized by high content of sialic acid, and can serve as a carrier of sialic acid, improving its absorption and bioavailability (Abdou et al. 2013). Hydrolyzed livetin exhibit a bone growth promotion activity and osteoprotective effect by increasing preosteoblastic MC3T3-E1 cell proliferation, alkaline phosphatase activity and suppressing osteoclastogenesis from bone marrow-derived precursor cells, respectively (Kim et al. 2010; Abdou et al. 2013). Egg YP may serve as a source of antihypertensive peptides. Oligopeptides of molecular mass lower than $1 \mathrm{kDa}$, obtained from enzymatic hydrolysis of whole egg yolk with the use a crude enzyme from the Rhizopus, suppress the development of hypertension in spontaneously hypertensive rats (SHR) (Yoshii et al. 2001). This effect might be explained by oligopeptides inhibitory activity shown against angiotensinconverting enzyme (ACE) (EC 3.4.15.1) which increases blood pressure and the heart rate (Yoshii et al. 2001).

Considerable research has been conducted to develop methods for the production and isolation of bioactive peptides from delipidated egg YP - the main by-products of lecithin extraction from hen egg yolks, as have been already documented by our research team (Eckert et al. 2014; Zambrowicz et al. 2015a, b). The usage of proteinaceous by-products for preparation of bioactive peptides by enzymatic hydrolysis may reduce the cost of peptide production and provide an interesting method of waste disposal. In our previous study, we demonstrated strong antioxidant and angiotensin I-converting enzyme (ACE) inhibitory activity of peptides generated and isolated from the peptic hydrolysate (YINQMPQKSRE, YINQMPQKSREA, VTGRFAGHPAAQ, YIEAVNKVSPRAGQF) and obtained after hydrolysis with protease from Cucurbita ficifolia (AGTTCLFTPLALPYDYSH, LAPSLPGKPKPD, RASDPLLSV RNDDLNYIQ). (Zambrowicz et al. 2015a, b; Eckert et al. 2014). Furthermore, we have proven that peptides: LAPSLPGKPKPD and VTGRFAGHPAAQ possessed antidiabetic activity, as demonstrated by significant inhibition of $\alpha$-glucosidase activity in vitro (Zambrowicz et al. 2015a, b). We confirmed the multidirectional biological activity of synthetic analogs of YP-derived peptides (Zambrowicz et al. 2015a, b; Eckert et al. 2014).

Peptides derived from egg YP have potential to be used as an attractive components for nutraceutical and pharmaceutical applications. The development of biotechnological solutions to obtain bioactive peptides is already in progress. Studies in this area are focused on reducing the processing time and costs. Therefore, in this paper, we demonstrated the use protein by-products and unconventional highly specific enzymes to generate biologically active peptides. The objectives of this study were: evaluation of the antioxidant and ACE-inhibitory activity of hydrolysates obtained from by-product of egg-yolk phospholipid extraction with the use of unconventional proteases from Yarrowia lipolytica JII1c yeast (I), bio-peptide isolation (II) and identification (III).

\section{Materials and Methods}

\section{Substrate}

The 40-45 weeks old laying hens of Lohman brown line were housed in a bedding system. Eggs were broken out, and yolks were separated on industry scale. Egg YP, a by-product of phospholipid extraction using ethanol was obtained according to method of Siepka et al. (2010), and used as substrate.

\section{Proteases}

Yarrowia lipolytica JII1c used in this study was originated from the yeast culture collection of the Department of 
Biotechnology and Food Microbiology, Wrocław University of Environmental and Life Sciences in Poland. Preparations of serine protease (Yls) and aspartyl protease (Yla) were obtained from a submerged culture of yeast in a mineralorganic mediums at $\mathrm{pH} 7.5$ and $\mathrm{pH} 3.5$, respectively. Biosynthesis of Yls was carried out at $28^{\circ} \mathrm{C}$ in $300 \mathrm{~mL}$ volumetric flasks containing $50 \mathrm{~mL}$ of the production medium composed of $(\mathrm{g} / \mathrm{L}$ ) yeast extract (1.7), isoelectric casein (4.0), fatty acids - $\mathrm{a}$ by-product of rapeseed oil refining (10.0), $\mathrm{KH}_{2} \mathrm{PO}_{4}(0.5), \mathrm{MgSO}_{4} \cdot 7 \mathrm{H}_{2} \mathrm{O}(0.25), \mathrm{NH}_{4} \mathrm{Cl}$ (1.0). Inoculum cultures were carried out for $24 \mathrm{~h}$ at $28^{\circ} \mathrm{C}$ in $\mathrm{YM}$ medium, containing $(\mathrm{g} / \mathrm{L})$ : yeast extract (3.0), maltose extract (3.0), bacto-peptone (5.0), glucose (10.0), and agar (20.0). All of the cultures were cultivated for $24 \mathrm{~h}$. After cultivation, the biomass was centrifuged at $5000 \times g$ for $15 \mathrm{~min}$ at $4{ }^{\circ} \mathrm{C}$. The obtained supernatants were concentrated and purified at $4{ }^{\circ} \mathrm{C}$ using a set of Amicon Bioseparations filtration membranes of regenerated cellulose (Millipore) with a nominal cut-off of $10 \mathrm{kDa}$.

\section{Determination of Protein Content}

Protein content was determined by the method described by Lowry et al. (1951).

\section{Determination of Proteolytic Activity}

Proteolytic activity of serine protease was determined in reaction with $2 \%$ casein as a substrate at $\mathrm{pH} 7.5$ (modified method of Chrzanowska and Kołaczkowska 1998). The reaction was conducted for $10 \mathrm{~min}$. at $37^{\circ} \mathrm{C}$ and then stopped by the addition of 5\% trichloroacetic acid (TCA). The samples were then centrifuged, and the absorbance of supernatants were measured at $\lambda=280 \mathrm{~nm}$. Proteolytic activity of aspartyl protease was measured in reaction with $2 \%$ hemoglobin at $\mathrm{pH} 3.5$. One unit of enzymatic activity (U) was defined as the amount of enzyme giving an increase in absorbance at $280 \mathrm{~nm}$ of 0.1 under reaction conditions.

\section{Enzymatic Hydrolysis}

The $1 \%$ of YP suspensions in $0.1 \mathrm{M}$ Tris- $\mathrm{HCl}$ buffer $(\mathrm{pH}$ 8.0) or $0.05 \mathrm{M}$ Gly- $\mathrm{HCl}$ buffer ( $\mathrm{pH} 3.5$ ) were hydrolyzed at $37^{\circ} \mathrm{C}$ for $4 \mathrm{~h}$ using Yls and Yla, respectively. 20 and/or 40 units of active proteases were applied per each $1 \mathrm{mg}$ of hydrolyzed YP. Additionally, sequential hydrolysis was conducted. For the first $2 \mathrm{~h}$ YP was hydrolyzed with the use Yls $(20 \mathrm{U} / \mathrm{mg}$ ) of hydrolyzed protein, then the $\mathrm{pH}$ was adjusted to 3.5 with using $1 \mathrm{~mol} / \mathrm{L} \mathrm{HCl}$ and reaction was continued for next $2 \mathrm{~h}$ after addition of Yla $(20 \mathrm{U} / \mathrm{mg})$. The reaction was terminated by heating the mixture at $100{ }^{\circ} \mathrm{C}$ for $15 \mathrm{~min}$. The hydrolysates were cooled, centrifuged $(5500 \times g, 10 \mathrm{~min}$, $10{ }^{\circ} \mathrm{C}$ ), then the supernatants were lyophilized and stored at $4{ }^{\circ} \mathrm{C}$ until used.

\section{Degree of Hydrolysis}

Degree of hydrolysis (DH) (\%) was determined as the percentage ratio of protein soluble in $10 \%$ TCA to total protein (Silvestre 1996). TCA was added to the hydrolysates (1:1) and after $1 \mathrm{~h}$ of incubation at $4{ }^{\circ} \mathrm{C}$ the samples were centrifuged $\left(4500 \times g, 15 \mathrm{~min}, 20^{\circ} \mathrm{C}\right)$. The concentration of the TCA-soluble product was measured spectrophotometrically at $\lambda=280 \mathrm{~nm}$, and calculated from the following equation:

$$
\begin{aligned}
\mathrm{DH}(\%)= & (\mathrm{mg} \text { soluble protein after hydrolysis } / \mathrm{mL} \\
& -\mathrm{mg} \text { soluble protein before hydrolysis } / \mathrm{mL}) \\
& \times 100 \%
\end{aligned}
$$

\section{The Content of Free Amino Acid Groups}

The content of free amino acid groups (FAG) $(\mu \mathrm{moL} / \mathrm{g})$ was determined using spectrophotometric assay with the use trinitrobenzene sulfonic acid (TNBS) (Kuchroo et al. 1983).

\section{Determination of ACE-Inhibitory Activity}

ACE (EC 3.4.15.1) inhibitory activity was measured using assay described by Miguel et al. (2004). A sample (hydrolysate, peptide fraction, peptide) $(40 \mu \mathrm{L})$ mixed with the Hippuryl-His-Leu (HHL) substrate solution $(5 \mathrm{mmol} / \mathrm{L}$ in $100 \mathrm{mmol} / \mathrm{L}$ potassium phosphate buffer containing $300 \mathrm{mmol} / \mathrm{L}$ sodium chloride, $\mathrm{pH}$ 8.3) was preincubated at $37{ }^{\circ} \mathrm{C}$ for $5 \mathrm{~min}$ and the reaction was initiated by adding $20 \mu \mathrm{L}(2 \mathrm{mU})$ of ACE solution and incubated for next $30 \mathrm{~min}$. The enzymatic reaction was terminated by the addition of $150 \mu \mathrm{L}$ of $1 \mathrm{M} \mathrm{HCl}$. The brought hippuric acid was extracted by $1 \mathrm{~mL}$ of ethyl acetate with vigorously shaking and after that, $750 \mu \mathrm{L}$ of the upper layer was transferred into a test tube and evaporated under vacuum. The hippuric acid left in the tubes was re-dissolved in $800 \mu \mathrm{L}$ of distilled water and the absorbance was measured at $\lambda=228 \mathrm{~nm}$.

All samples were tested in three replications. The inhibition activity was calculated using the following equation:

Inhibition activity $(\%)=[(\mathrm{A}--\mathrm{B}) / \mathrm{A}] \times 100 \%$

where $\mathrm{A}$ is the reaction blank, of which the mixture contained the same volume of the buffer solution instead of the ACE inhibitor sample; B is the reaction in the presence of both ACE and its inhibitor. 
The ACE inhibition percentages (according to equation) were measured for a series different concentrations of peptide fractions. And the $50 \%$ inhibition $\left(\mathrm{IC}_{50}\right)$ value was estimated from a dose response curve of an inhibitor versus the ACE activity.

\section{Amino Acid Composition}

Amino acid analysis was performed at BioCentrum Ltd. (Kraków, Poland). The protein samples were hydrolyzed in gas phase using $6 \mathrm{M} \mathrm{HCl}$ at $115^{\circ} \mathrm{C}$ for $24 \mathrm{~h}$. The liberated amino acids were converted into phenylthiocarbamyl derivatives and analyzed by high-pressure liquid chromatography (HPLC) on a PicoTag $3.9 \times 150 \mathrm{~mm}$ column (Waters, Milford, MA, USA).

\section{Determination of Antioxidant Activity as the Ability to Scavenge DPPH Free Radicals}

The antioxidant activity of the obtained hydrolysates and peptide fractions was assessed on the basis of the radical scavenging effect of the 1,1-diphenyl-2-picrylhydrazylfree radical activity according to Yen and Chen (1995), with minor modifications. The tested samples were dissolved in water to a final volume of $1 \mathrm{~mL}$ and mixed with $1 \mathrm{~mL}$ of ethanol (98\%). The reaction was started by adding $0.5 \mathrm{~mL}$ of $0.3 \mathrm{M} \mathrm{DPPH}$ in ethanol. The mixtures were left for $30 \mathrm{~min}$ at room temperature and the absorbance of the resulting solutions was measured at $517 \mathrm{~nm}$. For calibration, aqueous solutions of known Trolox concentrations ranging from 2 to $20 \mu \mathrm{g}$ (able to scavenge $500 \mu \mathrm{L}$ of $0.3 \mathrm{mM}$ DPPH radical solution) were used. Radical scavenging activity of the peptides was expressed as $\mu \mathrm{M}$ trolox $_{\mathrm{eq}} / \mathrm{mg}$ protein.

\section{FRAP Method}

To determine the antioxidative capacity of hydrolysates and peptide fractions the ferric reducing antioxidant power (FRAP) method was used (Benzie and Strain 1996). $3 \mathrm{~mL}$ of FRAP working solution [300 mM acetate buffer $\mathrm{pH}$ 3.6; $10 \mathrm{mM} \mathrm{2,4,6,tripyridyl-s-triazine} \mathrm{(TPTZ)} \mathrm{and} 20 \mathrm{mM}$ $\left.\mathrm{FeCl}_{3} \cdot 6 \mathrm{H}_{2} \mathrm{O}(10: 1: 1 \mathrm{v} / \mathrm{v})\right]$ was mixed with $1 \mathrm{~mL}$ of the sample. After $10 \mathrm{~min}$ of reaction, the absorbance was measured at $\lambda=593 \mathrm{~nm}$. An aqueous solution of known Fe(II) concentration was used for calibration. Results were expressed as $\mu \mathrm{g} \mathrm{Fe} \mathrm{F}^{2+} / \mathrm{mg}$ protein.

\section{Determination of Fe(II) Ion Chelation}

Chelation of iron ions by hydrolysates and peptide fractions was estimated by the method of Xu et al. (2007) with modifications. A $250 \mu \mathrm{L}$ sample was mixed with $1250 \mu \mathrm{L} \mathrm{H}_{2} \mathrm{O}$ and $110 \mu \mathrm{L} 1 \mathrm{mM} \mathrm{FeCl}_{2}$. After $2 \mathrm{~min}, 1 \mathrm{~mL}$ of $500 \mu \mathrm{M}$ ferrozine aqueous solution was added and the mixture was allowed to react for $10 \mathrm{~min}$. The absorbance of ferrous iron-ferrozine complex was measured spectrophotometrically at $\lambda=562 \mathrm{~nm}$. A known concentration of $\mathrm{FeCl}_{2}(0-20 \mu \mathrm{g})$ was used to generate a standard curve and the ability to chelate iron ions was expressed as $\mu \mathrm{g} \mathrm{Fe} \mathrm{Fe}^{2+} / \mathrm{mg}$ protein.

\section{Fractionation of the Hydrolysates Using Ultrafiltration}

The ultrafiltration was carried out in ultra/diafiltration system AMICON using the pressure of 1 bar. The selected hydrolyzates were fractionated by using membranes with molecular weight (MW) cut off of $30 \mathrm{kDa}$, in order to separate the enzyme, and then $5 \mathrm{kDa}$, in order to isolate the bioactive peptides. The peptide fractions having $\mathrm{MW}$ 5-30 $\mathrm{kDa}$ and $<5 \mathrm{kDa}$ were collected, lyophilized and stored at $4{ }^{\circ} \mathrm{C}$.

\section{Separation of the Peptides Fractions Using Gel Permeation Chromatography}

Gel permeation chromatography was performed using the HPLC column Zorbax GF-250 Agilent (4.6 mm $\times 250 \mathrm{~mm}$, $5 \mu \mathrm{m}$ ) on Agilent 1220 Infinity LC systems with DAD detector and OpenLab software. $50 \mu \mathrm{L}$ of sample was injected on the column and the peptide fractions were eluted with $0.02 \mathrm{M}$ Tris $\mathrm{HCl}$ buffer ( $\mathrm{pH}$ 6.8) containing $0.2 \mathrm{M} \mathrm{NaCl}$ at $30{ }^{\circ} \mathrm{C}$ and at a flow rate of $0.25 \mathrm{~mL} / \mathrm{min}$. The eluent was monitored at $\mathrm{A}_{230} \mathrm{~nm}$. To obtain a great concentrations of peptides, chromatography was a few times repeated. Then fractions were collected, dialyzed against water with the use dialysis tubing cellulose membrane (1 kDa) and lyophilized.

\section{Reversed-Phase High-Performance Liquid Chromatography}

Peptide profile of analyzed hydrolysate and separation was performed using reversed-phase high-performance liquid chromatography (RP-HPLC) on Agilent 1220 Infinity LC systems with DAD detector and OpenLab software. Analysis of the whole peptide profile of hydrolysate was performed on Zorbax XDB-C 18 Agilent column $(4.6 \times 50 \mathrm{~mm}, 1.8 \mu \mathrm{m})$. The operation conditions were as follows: injection volume: $20 \mu \mathrm{L}$; mobile phase $\mathrm{A}-0.1 \%$ TFA in water; mobile phase $\mathrm{B}-0.1 \%$ TFA in acetonitrile, column temperature: 
$30{ }^{\circ} \mathrm{C}$, flow rate $1 \mathrm{~mL} / \mathrm{min}$., and gradient (starting after $60 \mathrm{~s}$. from the sample injection) condition was from 0 to $100 \% \mathrm{~B}$ $(10 \% \mathrm{~B} / \mathrm{min})$. The absorbance of eluent was monitored at $\lambda=230 \mathrm{~nm}$.

Zorbax XDB-C 18 Agilent columns at two different sizes $[4.5 \mathrm{~mm} \times 250 \mathrm{~mm}, 5.0 \mu \mathrm{m}$ (RP-HPLC step 1,2) and $4.5 \mathrm{~mm} \times 150 \mathrm{~mm}, 5.0 \mu \mathrm{m}$ (RP-HPLC step 3)] were used in order to achieve better separation of peptide fractions.

The operation conditions were as follows: injection volume: $100 \mu \mathrm{L}$; mobile phase $\mathrm{A}-0.1 \%$ TFA in water; mobile phase $\mathrm{B}-0.1 \%$ TFA in acetonitrile, column temperature: $30{ }^{\circ} \mathrm{C}$, flow rate $1 \mathrm{~mL} / \mathrm{min}$, and gradient condition was varied ( $1 \% \mathrm{~B} / \mathrm{min}$ for RP-HPLC step $1 ; 2.4 \% \mathrm{~B} / \mathrm{min}$ for RPHPLC step 2 and $3.8 \% \mathrm{~B} / \mathrm{min}$ for RP-HPLC step 3). The absorbance of eluents was monitored at $\lambda=230 \mathrm{~nm}$. To obtain a great concentrations of peptides, chromatography at each step was a few times repeated. Then fractions were collected, dialyzed against water with the use of dialysis tubing cellulose membrane $(1 \mathrm{kDa})$ and lyophilized.

\section{Determination of Peptide Molecular Weight}

Lyophilisate of peptide fraction collected from RP-HPLC was diluted in $60 \mu \mathrm{L}$ of acetonitrile (60\%) and centrifuged. Supernatant was dried and then diluted in $10 \mu \mathrm{L}$ of acetonitrile (50\%). On the steel tile of spectrometer $0.5 \mu \mathrm{L}$ of the sample and $0.5 \mu \mathrm{L}$ of alpha-cyano-4-hydroxycinnamic acid solution were applied and dried. The molecular masses of the isolated peptide fraction was determined using an UltrafleXtreme Maldi ToF/ToF (Bruker Daltonics, Germany), in a positive ion mode. Software FlexControl, FlexAnalysis, BioTools and ProteinScape (Bruker Daltonics, Germany) was used. The substances corresponding with the ion signals observed on the MS spectra were identified using: Macsot Search Results database SwissProt.

\section{Statistical Analysis}

Each type of hydrolysate was prepared in two independent batches. The biological activity measurements of hydrolysates as well as various fractions obtained in the purification process were done in triplicate for each hydrolysate. The obtained data are the mean of three independent determinations. Statistical significance of the differences was determined by Duncan's $t$ test $(\mathrm{p}<0.05)$.

\section{Results and Discussion}

\section{Preparation of Peptides with Biological Activity from the Egg Yolk Protein By-product}

YP was hydrolyzed with noncommercial serine and aspartyl proteases from Y. lipolytica JII1c yeast. The progress of hydrolysis was monitored by determining the DH (\%) and the concentration of the FAG (Table 1). The proteolytic action of yeast proteases resulted in YP degradation reaching a DH values in a range from 8.20 to $34.0 \%$, after $4 \mathrm{~h}$ digestion. The analysis of the FAG concentration (from 50.8 equal to $3543.20 \mu \mathrm{M} \mathrm{Gly} / \mathrm{g}$ ) of obtained hydrolysates confirmed the above results (Table 1). Serine protease (YLs) exert greater proteolytic activity toward YP than aspartyl protease (YLa). However, sequential use of YLs and then YLa have resulted in the highest increase of FAG concentration after $4 \mathrm{~h}$ of YP degradation $(3543.20 \mu \mathrm{M}$ Gly/g).

The antioxidant activity of the YP hydrolysates was studied in terms of its scavenging effect on DPPH radicals, reducing power (FRAP), iron chelating activity. In addition, ACE-inhibitory activity was also evaluated (Table 1). As demonstrated in Table 1, serine protease (YLs) has greater ability to release bioactive peptides from the YP
Table 1 DH and biological activities of $4 \mathrm{~h}$ egg-yolk protein by-product (YP) hydrolysates treated by proteases from $Y$. lipolytica yeast JII1c

\begin{tabular}{|c|c|c|c|c|c|c|}
\hline Hydrolysate & $\mathrm{DH}(\%)$ & FAG $(\mu \mathrm{MGly} / \mathrm{g})$ & $\begin{array}{l}\mathrm{DPPH}(\mu \mathrm{M} \\
\text { trolox/mg) }\end{array}$ & $\begin{array}{l}\text { FRAP } \\
\left(\mu \mathrm{g} \mathrm{Fe}{ }^{2+} /\right. \\
\mathrm{mg})\end{array}$ & $\begin{array}{l}\text { Chelation } \\
\left(\mu \mathrm{g} \mathrm{Fe}{ }^{2+} /\right. \\
\mathrm{mg})\end{array}$ & $\begin{array}{l}\text { ACE inhibitory } \\
\text { effect }\left(\mathrm{I}_{\mathrm{C} 50}\right)(\mu \mathrm{g})\end{array}$ \\
\hline Substarte & $0^{\mathrm{a}}$ & $50.8\left(11129.07^{\mathrm{f}}\right)^{*}$ & $0.44^{\mathrm{a}}$ & $35.79^{\mathrm{c}}$ & $292.8^{\mathrm{b}}$ & $0^{\mathrm{a}}$ \\
\hline YLs 20U* & $12.00^{\mathrm{c}}$ & $1302.80^{\mathrm{a}}$ & $0.52^{\mathrm{b}}$ & $62.76^{\mathrm{d}}$ & $485.68^{d}$ & $3.92^{\mathrm{c}}$ \\
\hline YLs 40U* & $34.00^{\mathrm{f}}$ & $2831.80^{\mathrm{d}}$ & $2.75^{\mathrm{e}}$ & $88.25^{\mathrm{f}}$ & $419.99^{c}$ & $1.08^{\mathrm{b}}$ \\
\hline YLa 20U* & $8.20^{\mathrm{b}}$ & $1651.10^{\mathrm{b}}$ & $0.50^{\mathrm{b}}$ & $86.60^{\mathrm{e}}$ & $298.50^{\mathrm{b}}$ & $15.79^{\mathrm{f}}$ \\
\hline YLa 40U* & $14.10^{\mathrm{d}}$ & $2143.70^{\mathrm{c}}$ & $0.61^{\mathrm{c}}$ & $28.15^{\mathrm{b}}$ & $276.32^{\mathrm{a}}$ & $6.62^{\mathrm{e}}$ \\
\hline YLa 20U*/YLs20U* & $31.30^{\mathrm{e}}$ & $3543.20^{\mathrm{e}}$ & $0.93^{\mathrm{d}}$ & $19.90^{\mathrm{a}}$ & $280.40^{\mathrm{a}}$ & $5.29^{\mathrm{d}}$ \\
\hline
\end{tabular}

All data were expressed as mean values $(n=3)$. Values sharing the same letter are not significantly different at $\mathrm{P}<0.05$

*The value of free amino groups after total hydrolysis with concentrated sulphuric acid

$\mathrm{U}^{*}$ units of active enzyme applied on every mg of substrate

$\alpha-0.05$ 
than aspartyl protease (YLa). YP hydrolysate obtained after using serine protease (YLs) for $4 \mathrm{~h}$, possessed the strongest potency in scavenging DPPH radicals $\left(2.75 \mu \mathrm{MTrolox}_{\mathrm{eq}}\right.$ ' $\mathrm{mg})$, ferric reducing capacity $\left(88.25 \mu \mathrm{g} \mathrm{Fe}{ }^{2+} / \mathrm{mg}\right)$ and chelating activity (419.99 $\mu \mathrm{g} \mathrm{Fe} 2+\mathrm{mg})$. This hydrolysate also possessed the strongest inhibitory activity (IC50 $=27 \mu \mathrm{g}$ / $\mathrm{mL}$ ) against $\mathrm{ACE}$ among all obtained hydrolysates. $\mathrm{DH}$ is an important factor controlling the composition and biological properties of the protein hydrolysates, and in most cases higher DH value provides greater biological activity (Table 1) (Liu et al. 2018). Also enzymes with specific activity, generating different type of peptides, have significant impact on their biological activity. The peptides obtained by hydrolysis with unconventional aspartyl proteinase from $Y$. lipolytica JII1c were characterized by much lower free radical scavenging activity (about 4.5-5.5 times lower than activity of other hydrolysates) and ACE-inhibitory activity. Similarly to our results, hydrolysis of the egg-yolk protein by-product with using various proteases including neutrase, porcine pepsin and protease from C. ficifolia, led to the production of peptides with varied antioxidant and antihypertensive activity (Zambrowicz et al. 2015a, b; Eckert et al. 2014; Pokora et al. 2013). In addition, simultaneous ability of enzymatic hydrolysates to scavenge of DPPH radicals and to inhibit of ACE have been demonstrated in other study (Davalos et al. 2004; Lu et al. 2010; Zambrowicz et al. 2015b).

\section{The Biological Activity of Peptide Fractions Isolated from the YP Hydrolysate}

The peptide isolation procedure included: ultrafiltration (cut-off $30 \mathrm{kDa}$ for enzyme isolation and $5 \mathrm{kDa}$-samples: $\mathrm{f}<5 \mathrm{kDa}, \mathrm{f}>5 \mathrm{kDa}$ ); size-exclusion chromatography and RP-HPLC (Fig. 1). The 4-h hydrolysate of YP obtained with using Yls (40 U/mg of hydrolysed protein) with the highest biological activity was ultrafiltered through a cellulose membrane (MWCO $30 \mathrm{kDa}$ ). Then the obtained permeate was ultrafiltered with using $5 \mathrm{kDa}$ cut-off membrane, in order to isolate and purify the bio-peptides. The peptide fractions with MWs lower than $5 \mathrm{kDa}$ exhibited 1.5, 1.6 and 1.28 times higher free radical scavenging, ferric reducing and ACE inhibitory activity, respectively, compared to unfractionated hydrolysate (Table 2). This suggests that lower-sized peptides may play a major role in antioxidant activity. Chay Pak Ting et al. (2011) developed laboratoryscale ultrafiltration processes to separate antioxidative peptides from tryptic hydrolysates of delipidated egg yolk protein. They obtained peptide fraction enriched in peptides with MW lower than $5 \mathrm{kDa}$, which was characterized by strong antioxidant activity, as determined by the oxygen radical absorbance capacity assay (Chay Pak Ting et al.
2011). Yousr et al. also showed that antioxidative peptides can be isolated with the use of cut-off membranes (Yousr and Howell 2015; Yousr et al. 2017). They obtained $2 \mathrm{kDa}$ fraction from 2-h hydrolysate of defatted egg yolk, which exert strong antioxidant activity. Further separation by gel filtration using Sephadex G-25 led to obtain peptide KLSDV with additional antiproliferative activity (Yousr et al. 2017). It was observed that ultrafiltration led to a drastic decrease in the chelating activity toward iron ions. In opposite, Jiang and Mine (2000) and Feng and Mine (2006) proven that phosphopeptides with a MW between 1 and $3 \mathrm{kDa}$, possess a significantly higher ability to chelating selected metal ions than the unfractionated phosvitin hydrolysates.

In the next step of peptide purification, the separated peptide fraction of MW lower than $5 \mathrm{kDa}$ was subjected to size exclusion chromatography (SEC) on a Zorbax GF-250 column. The SEC allowed the isolation of five fractions, which were collected, and evaluated for biological properties (Fig. 1). Among the five fractions, fraction number 5 possessed the highest DPPH scavenging (4.94 $\mu$ MTrolox $_{\mathrm{eq}} /$ $\mathrm{mg})$, ferric reducing $\left(163.24 \mu \mathrm{g} \mathrm{Fe}{ }^{2+} / \mathrm{mg}\right)$ and ACE inhibitory $\left(\mathrm{IC}_{50}=6.50 \mu \mathrm{g} / \mathrm{mL}\right)$ activities. Only fraction no. 5 possessed biological activity higher than peptide fraction of $\mathrm{MW}<5 \mathrm{kDa}$. Interestingly, it was observed direct interdependence between MWs of peptides eluted from GF-250 column and their DPPH scavenging and ACE inhibitory activities (data not shown).

The antioxidant property of protein hydrolysates is related to the amino acid composition and their sequence (Memarpoor-Yazdi et al. 2013; Chi et al. 2015). The amino acid profile of fraction no 5 from YP hydrolysate is shown in Table 3. The hydrophobic amino acids (Ala, Val, Leu, Pro, Met, Tyr, Phe, Trp) have significant impact on antioxidant activity of hydrolysates and peptides (Memarpoor-Yazdi et al. 2013; Chi et al. 2015). Especially, high content of Leu (15.03\%) and Val (10.64\%) provide high hydrophobicity that is important in performing antioxidant mechanisms (Bamdad et al. 2015). In addition, high serine content (21.29\%), which hydroxyl group act chelating trace elements such as iron, might contribute to the strong antioxidant and chelating activity shown by fraction 5 (Eckert et al. 2016) (Table 3).

Beta-lactoglobulin is an important source of biopeptides. Beta-lactoglobulin—derived peptides exert numerous activities including antihypertensive, antioxidant and antimicrobial activities, opioid-like features as well as ability to decrease the body-cholesterol levels (Hernández-Ledesma et al. 2008). Therefore amino acid composition of peptide fraction no. 5 was showed in comparison to Beta-lactoglobulin (Table 3). Interestingly, $\beta$-lactoglobulin contains almost five times lower level of serine than fraction no 5 . In contrast $\beta$-lactoglobulin contains much higher amounts of histidine, arginine, threonine and alanine. 

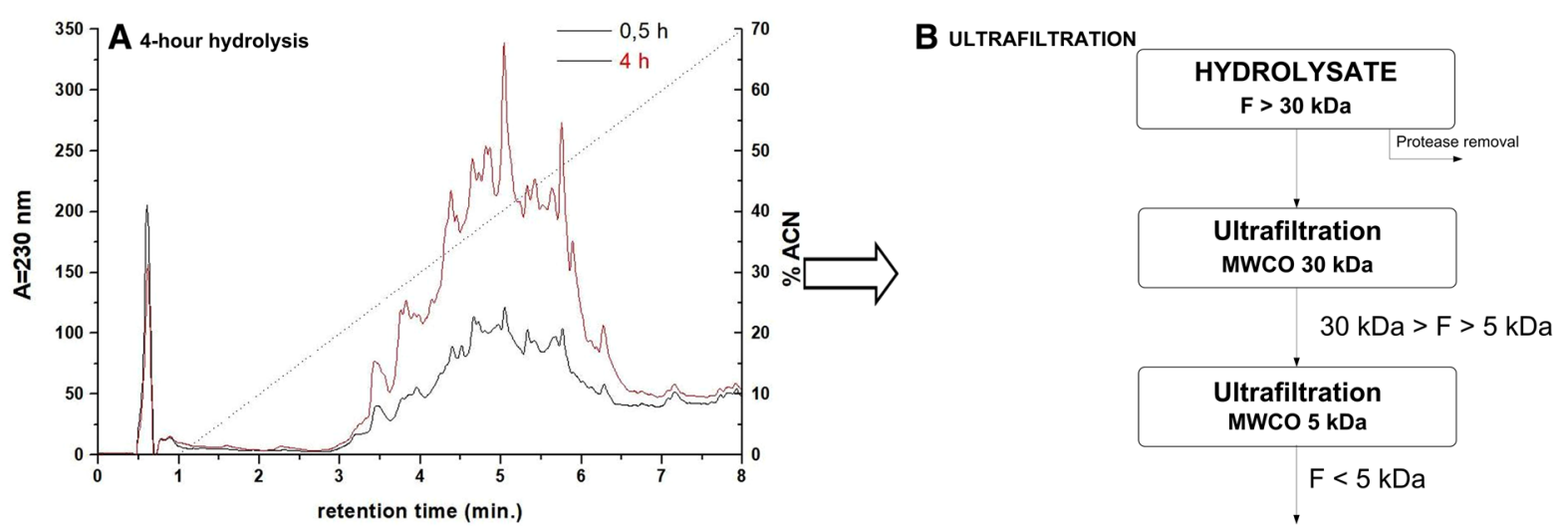

D RP-HPLC 1-step
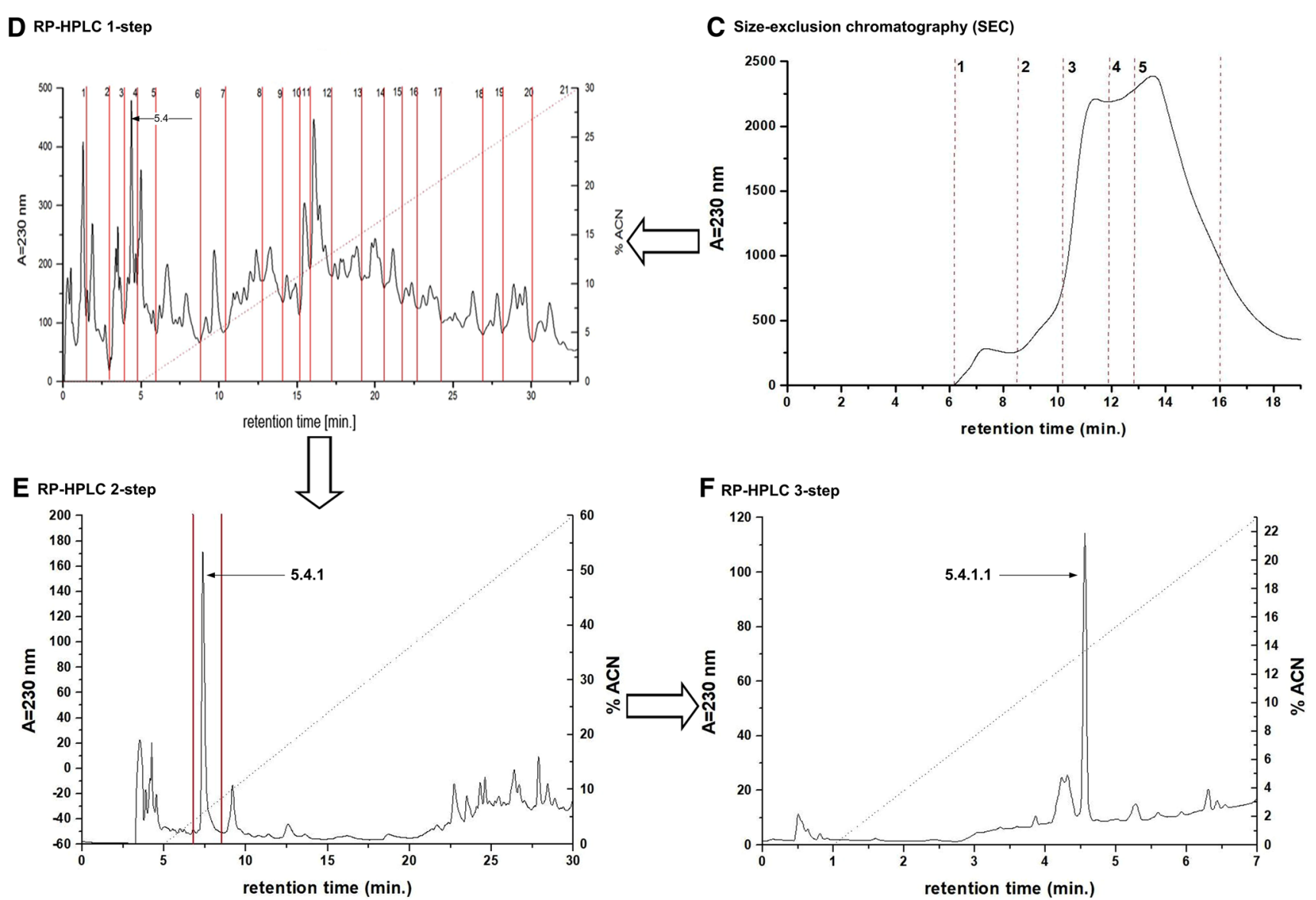

Fig. 1 Scheme of peptide isolation from $4 \mathrm{~h}$ egg-yolk protein byproduct (YP) hydrolysate treated by serine protease from $Y$. lipolytica yeast JII1c. a Peptide profile (RP-HPLC) of $4 \mathrm{~h}$ hydrolysate; b ultrafiltration; c size-exclusion chromatography of fraction of MW lower

than $5 \mathrm{kDa}$; d RP-HPLC of fraction no 5; e re-chromatography (RPHPLC) of fraction 5.4.; $\mathbf{f}$ re-chromatography (RP-HPLC) of fraction 5.4 .1

In our study, fraction 5 was further purified by RP-HPLC to obtain 21 (5.1-5.21, HPLC step 1) subfractions (Fig. 1). Evidently, the highest DPPH free radical scavenging activity was reached by fraction number $5.4\left(4.94 \mu \mathrm{M}\right.$ Trolox $_{\mathrm{eq}}$ l $\mathrm{mg}$ ) (Table 2). Additionally this fraction demonstrated the highest iron ion chelating ability $\left(253.89 \mu \mathrm{g} \mathrm{Fe} \mathrm{Fe}^{2+} / \mathrm{mg}\right)$.

However, the ability of this fraction to reduce the oxidation of iron ions was on the level of $163.24 \mu \mathrm{g} \mathrm{Fe}^{2+} / \mathrm{mg}$. While the strongest ability of reduce the oxidation of iron ions $\left(187.5 \mu \mathrm{g} \mathrm{Fe}{ }^{2+} / \mathrm{mg}\right.$ ) was estimated for fraction 5.12 (data not shown). It should also be noted that in all the cases, chelating activity significantly had decreased compared to 
Table 2 Biological activities of the peptide fractions separated by ultrafiltration, sizeexclusion and reverse-phase chromatography of $4 \mathrm{~h}$ eggyolk protein by-product (YP) hydrolysate treated by serine protease from $Y$. lipolytica yeast JII1c

\begin{tabular}{llllll}
\hline Purification step & Sample & $\begin{array}{l}\text { DPPH }(\mu \mathrm{M} \\
\text { trolox/mg })\end{array}$ & $\begin{array}{l}\text { FRAP }(\mu \mathrm{g} \\
\left.\mathrm{Fe}^{2+} / \mathrm{mg}\right)\end{array}$ & $\begin{array}{l}\text { Chelation }(\mu \mathrm{g} \\
\left.\mathrm{Fe}^{2+} / \mathrm{mg}\right)\end{array}$ & $\begin{array}{l}\text { ACE inhibitory } \\
\text { effect }\left(\mathrm{IC}_{50}\right) \\
(\mu \mathrm{g})\end{array}$ \\
\hline Hydrolysis & $4-\mathrm{h}$ hydrolysate & $2.75^{\mathrm{a}}$ & $88.25^{\mathrm{a}}$ & $419.99^{\mathrm{e}}$ & $1.08^{\mathrm{d}}$ \\
Ultrafiltration & $\mathrm{f}>5 \mathrm{kDa}$ & $4.13^{\mathrm{b}}$ & $141.67^{\mathrm{b}}$ & $100.16^{\mathrm{a}}$ & $0.84^{\mathrm{c}}$ \\
SEC & 5 & $4.94^{\mathrm{c}}$ & $163.24^{\mathrm{c}}$ & $269.60^{\mathrm{d}}$ & $0.26^{\mathrm{b}}$ \\
RP-HPLC & 5.4 & $4.98^{\mathrm{c}}$ & $178.04^{\mathrm{d}}$ & $253.89^{\mathrm{c}}$ & $0.25^{\mathrm{ab}}$ \\
RP-HPLC & 5.4 .1 & $5.0^{\mathrm{cd}}$ & $180.0^{\mathrm{d}}$ & $245.0^{\mathrm{b}}$ & $0.24^{\mathrm{a}}$ \\
RP-HPLC & 5.4 .1 .1 & $5.08^{\mathrm{d}}$ & $188.02^{\mathrm{e}}$ & $251.0^{\mathrm{c}}$ & $0.24^{\mathrm{a}}$ \\
\hline
\end{tabular}

All data were expressed as mean values $(n=3)$. Values sharing the same letter are not significantly different at $\mathrm{P}<0.05$
Table 3 Amino acid profile of peptide fraction number 5 obtained from size-exclusion chromatography of fraction of MW lower than $5 \mathrm{kDa}$

\begin{tabular}{lcc}
\hline Amino acid (\%) & Fraction 5 & $\beta$-Lacto globulin \\
\hline Asx $^{\mathrm{a}}$ & 16.08 & 6.13 \\
Glx $^{\mathrm{a}}$ & 13.25 & 17.65 \\
Ser & 21.29 & 4.44 \\
Gly & 11.45 & 2.90 \\
His & 0.15 & 1.50 \\
Arg & 0.05 & 2.64 \\
Thr & 0.30 & 5.48 \\
Ala & 0.15 & 10.83 \\
Pro & 7.43 & 6.43 \\
Tyr & 1.13 & 3.24 \\
Val & 10.64 & 7.22 \\
Met & 2.07 & 2.73 \\
Ile & 0.06 & 7.84 \\
Leu & 15.03 & 17.67 \\
Phe & 0.57 & 3.20 \\
Lys & 0.36 & 0.10 \\
\hline
\end{tabular}

${ }^{\mathrm{a}} \mathrm{Asx}=\mathrm{Asp}+\mathrm{Asn}, \mathrm{Glx}=\mathrm{Gln}+\mathrm{Glu}$

the initial sub-fraction (Table 2). RP-HPLC did not lead to significant increase of ACE inhibitory activity (data not shown). Fraction 5.4 was a mixture of peptides; therefore chromatography was repeated twice on a Zorbax XDB C18 column (Fig. 1). The procedure produced final peptide fraction 5.4.1.1 which was characterized by a significantly high DPPH radical scavenging $\left(5.08 \mu \mathrm{M}\right.$ Trolox $\left.{ }_{\mathrm{eq}} / \mathrm{mg}\right)$, reducing activity (FRAP) $\left(188.02 \mu \mathrm{g} \mathrm{Fe}{ }^{2+} / \mathrm{mg}\right)$ and ACE inhibitory activity $\left(\mathrm{IC}_{50}=6.0 \mu \mathrm{g} / \mathrm{mL}\right.$ ) (Table 2 ). Purified peptide fraction 5.4.1.1 was analyzed by mass spectrometry (Maldi-Tof) in order to identify the bioactive peptide sequences (Fig. 2). The protein origin of peptide sequence was identified using Mascot Search Results database (Fig. 3a, b). The analysis indicated that peptide sub-fraction consists one peptide of 10 amino acid residues with the following sequence: QSLVSVPGMS (fragment of aryl hydrocarbon receptor nuclear translocator-like protein 2). Amino acids, such as Tyr, Lys, Arg, Gly, Leu and His present in the peptide sequence are mainly responsible for antioxidant ability (MemarpoorYazdi et al. 2013). The presence of Gln (Q) and Pro (P) which have electron-dense side chains (the pyrrolidine ring of Pro and the amide group of Gln) have a strong impact on DPPH scavenging activity, where the free radical are inactivated by electron donation from those particular amino acids (Bamdad et al. 2015). Also serine hydroxyl groups could serve as hydrogen donors, thus acting as hydroxyl radical scavengers (Eckert et al. 2016). Carboxyl group of Gln in QSLVSVPGM peptide are also able to make an ionic bond with a positively charged iron ions, while the amine functional groups can form a coordinate bond and contribute to chelating ability of the peptide (Bamdad et al. 2015; Eckert et al. 2016). Other studies have reported that methionine residues affect significantly on antioxidant protection mechanism. Exposed methionine residue works as a reactive site that scavenges oxidants through the formation of a sulfoxide structure after oxidation to stop free-radical chain reactions (Wu et al. 2018).

The proteolytic degradation of YP with using unconventional serine protease from $Y$. lipolytica yeast JII $1 \mathrm{C}$ also led to obtain peptide fractions with ACE inhibitory activity. We have proven in our previous reports that the production of valueadded protein hydrolysates from egg yolk protein by-product (YP) may provide an alternative source for obtaining ACE inhibitory peptides for preventing hypertension (Eckert et al. 2014; Zambrowicz et al. 2015a, b).

The molecular interactions between ACE and the ACE inhibitory peptides have been studied by Liu et al. (2018). They have proven that peptides: AVKVL, YLVR and TLVGR purified from hazelnut protein hydrolysates had high-binding affinities with the enzyme and could easily form a complex 
Fig. 2 Determination of peptide MW and sequence. MS-Maldi ToF spectrum of fraction 5.4.1.1 isolated from $4 \mathrm{~h}$ eggyolk protein by-product (YP) hydrolysate

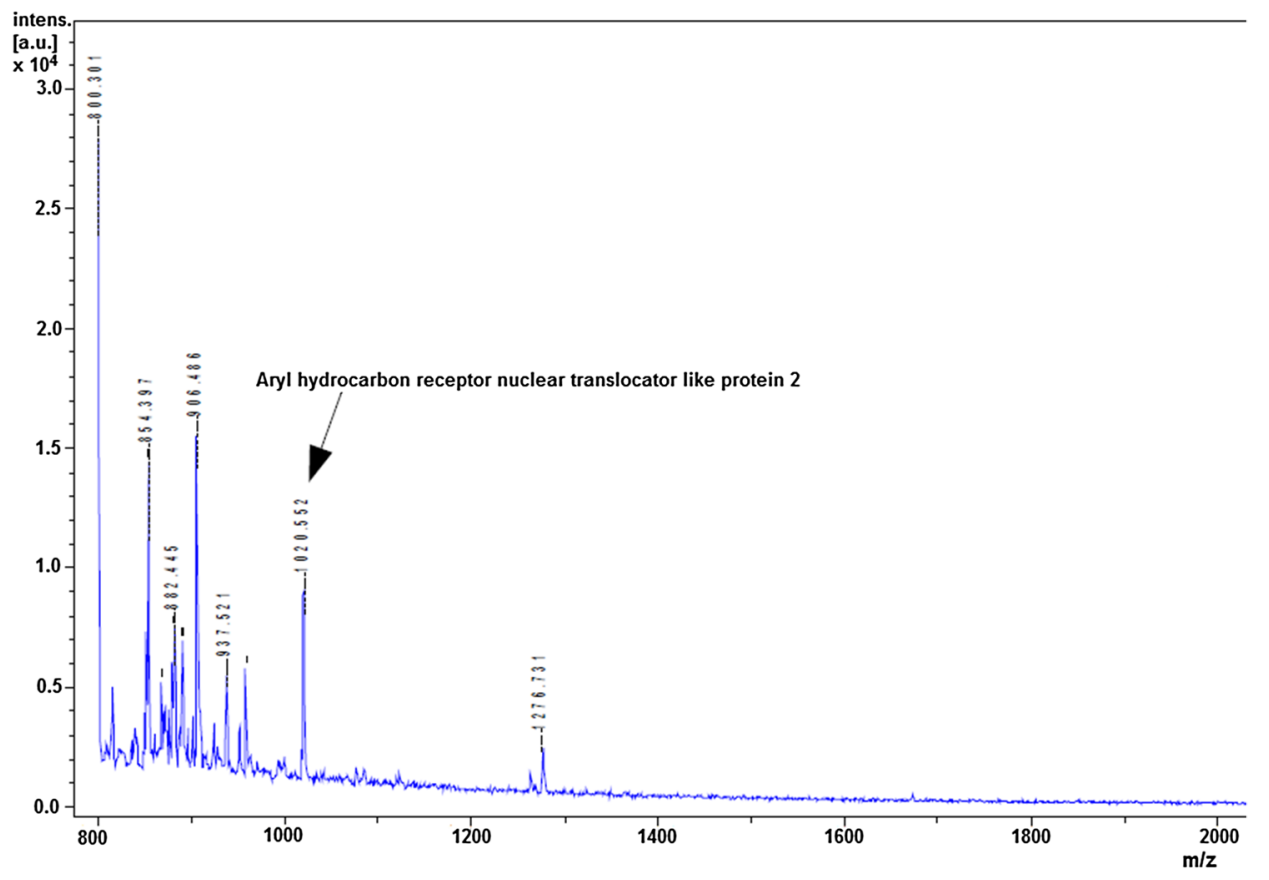

with ACE. They showed that Leu (L) residue significantly affected ACE inhibition. Lee and Hur (2017) also revealed that several ACE inhibitory peptides with low $\mathrm{IC}_{50}$ values contained the leucine hydrophobic residue, including KPLL, VLAQYK and DLP. Furthermore, a common feature of almost all obtained peptides is the presence of proline residues in their sequence likely indicating the positive effect of Pro in stabilizing the peptide-ACE complex formation $(\mathrm{Wu}$ et al. 2006).

The immunomodulators from natural sources which are able to activate immune cells like macrophages and blood $\mathrm{T}$ and $\mathrm{B}$ lymphocytes are crucial for the development and maintenance the effective immune response to pathological factors from the environment. Therefore we conducted the pilot studies on the immunostimulating activity of 4-h hydrolysate obtained with the use of serine protease from $Y$. lipolytica yeast. Hydrolysate at doses of 10 and $100 \mu \mathrm{g} / \mathrm{mL}$ strongly stimulated the whole human blood cells to release anti-inflammatory cytokine-IL-10 (data not shown).

\section{Conclusion}

This study showed that protein by-product obtained after phospholipid extraction from hen egg yolks constitutes a promising source of biologically active peptides. Peptides with antioxidant and antihypertensive activity could be released using non-commercial serine proteinase of $Y$. lipol$y$ tica yeast. Free radical scavenging capacity, $\mathrm{Fe}^{2+}$ chelating effect, reducing power (FRAP) and ACE-inhibitory activity were tested. Proposed isolation procedure led to obtain QSLVSVPGMS peptide with almost 2-times higher DPPH radical scavenging activity and over three times higher ACE-inhibitory activity compared to initial hydrolysate. Our results revealed, that developed method with using the egg protein waste product from industrial process as well as unconventional and cheap enzyme, could be considered as an effective and competitive way of producing new bio-peptide preparations. 
a

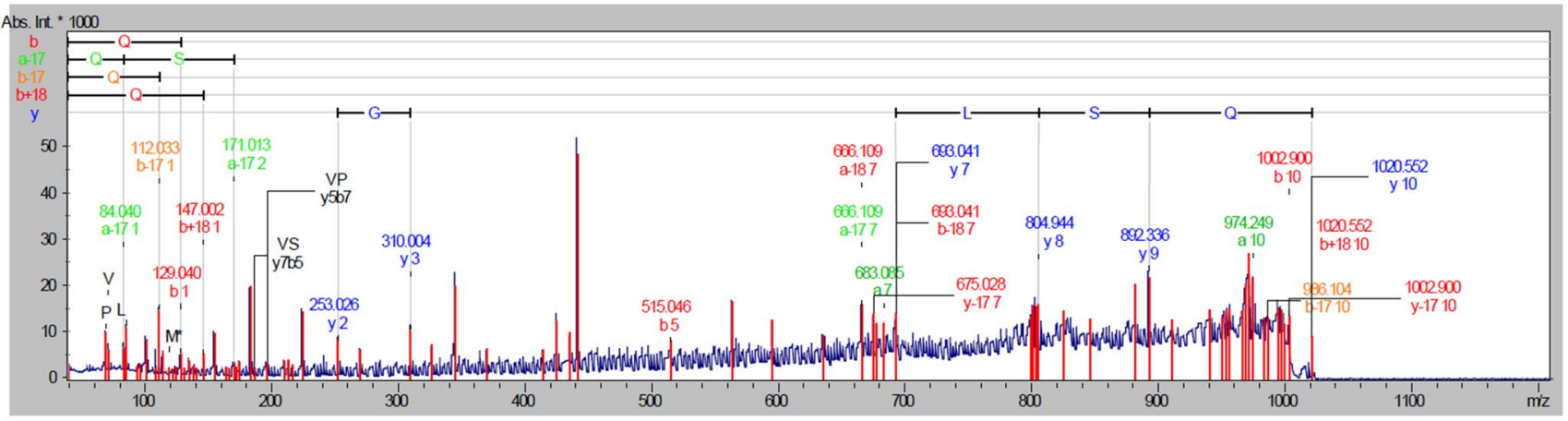

b

Nominal mass $\left(\mathrm{M}_{\mathrm{r}}\right)$ : 69088; Calculated pI value: 5.66

Taxonomy: Gallus gallus

Variable modifications: Oxidation (M)

No enzyme cleavage specificity

Sequence Coverage: 1\%

Matched peptides shown in Bold Red

1 MAEAGVGSAE GAEEERRAVE ENFPVDGNSC IASGVPSLMN PITKPATTSE

51 NNSVVEIPRK RKGSDSDNQD TVEVDGDPQK RNEDEEHLKI KDFREAHSQT

101 EKRRRDKMNN IIEELSAMIP OCNPMARKLD KLTVLRMAVQ HLKSLKGSTS

151 SYTEVRYKPS FLKDDELRQL ILRAADGELF VVGCNRGKIL FVSESVCKIL

201 NYDQTSLIGQ SLFDYLHPKD VAKVKEQLSS SDVSPREKLV DGKTGLQVHT

251 DEQAGPARLN SGARRSEFCR IKCSRTTVKE EKECLPNPKK KDHRKYCTIH

301 CTGYMKNWPP SEVGVEEEND VEKNSSNENC LVAIGRLHPY IVPOKSGEIK

351 VKATEFVTRF AMDGKFVYVD QRATAILGYL PQELLGTSCY EYCHQDDHNH

401 LAEKHKEVLQ NKEKVETNSY KFRAKDGSEI TLKSQWESFM NPWTKELEYI

451 VSNNTVVLGH NESAEEQVSY GSQPAEGAVK QSLVSVPGMS SGTVLGAGSI

501 GTEIANEILE LORLHSSPPG ELSPSHLLRK SPSPALTVNC SNVPNKELIO

551 LCPSEAEVLE TSEQNQGAIP FPSNEPLLGG NSQLDFAICE NDDTAMTALM

601 NYLEADGGLG DPAELSDIQW AL

Residue Number Increasing Mass Decreasing Mass

$\begin{array}{rrcccc}\text { Start - End } & \text { Observed } & \text { Mr (expt) } & \text { Mr(calc) } & \text { Delta } & \text { Miss Sequence } \\ 481-490 & 1020.5519 & 1019.5446 & 1019.4958 & 0.0489 & 0 \\ \text { K.QSLVSVPGM.S }\end{array}$

Fig. 3 Mascot search results analysis of MS spectrum of peptide fraction 5.4.1.1. a MS-Maldi ToF spectrum, $\mathbf{b}$ data from Mascot search results analysis

Acknowledgements Project "Innovative technologies in the production of bio-preparations based on new generation eggs," Innovative Economy Operational Programme Priority 1.3.1, thematic area "Bio", co-financed by the European Union through the European Regional Development Fund within the Innovative Economy Operational Programme, 2007-2013. This project was supported by the Wroclaw Centre of Biotechnology programme, The Leading National Research Centre (KNOW), 2014-2018.

\section{Compliance with Ethical Standards}

Conflict of interest All the authors who have taken part in this study declare that they have nothing to disclose regarding competing interests, or funding from industry with respect to this manuscript.

Open Access This article is distributed under the terms of the Creative Commons Attribution 4.0 International License (http://creativeco mmons.org/licenses/by/4.0/), which permits unrestricted use, distribution, and reproduction in any medium, provided you give appropriate credit to the original author(s) and the source, provide a link to the Creative Commons license, and indicate if changes were made.

\section{Glossary}

ACE: Angiotensin converting enzyme; BDNF: Brainderived neurotrophic factor; BMDM: Bone-marrow mouse macrophages; DH: Degree of hydrolysis; DPPH: 1,1-Diphenyl-2-picrylhydrazyl free radical; FAG: Free amino acid groups; FRAP: Ferric reducing antioxidant power; HHL: Hippuryl-His-Leu; HPLC: Highpressure liquid chromatography; IL: Cytokine-interleukin; PC12: Rat pheochromocytoma cells; ROS: Reactive oxygen species; RP-HPLC: Reversed-phase high-performance liquid chromatography; SEC: Size: exclusion chromatography; SHR: Spontaneously hypertensive rats; TCA : Trichloroacetic acid; TNBS: Trinitrobenzene sulfonic acid; TNF: Tumor necrosis factor; TPTZ: 2,4,6,Tripyridyls-triazine; Y. lipolytica JII1c: Yarrowia lipolytica JII1c; Yla: Aspartyl protease from Y. lipolytica JII1c; Yls: Serine protease from Y. lipolytica JII1c; YM: Yeast medium; YP: Egg yolk protein by-product 


\section{References}

Abdou AM, Kim M, Sato K (2013) Functional proteins and peptides of hen's egg origin. In: Hernandez-Ledesma B, Hsieh CC (eds) Bioactive food peptides in health and disease. Croatia-European Union, Rijeka, pp 115-144. ISBN 978-953-51-0964-8 (CCBY z.o license)

Admassu H, Abdalbasit Gasmalla MAA, Yang R, Zhao W (2018) Bioactive peptides derived from seaweed protein and their health benefits: antihypertensive, antioxidant, and antidiabetic properties. J Food Sci 83(1):6-16

Bamdad F, Ahmed S, Chen L (2015) Specifically designed peptide structures effectively suppressed oxidative reactions in chemical and cellular systems. J Funct Foods 18:35-46

Benzie IFF, Strain JJ (1996) The ferric reducing ability of plasma (FRAP) as a measure of antioxidant power: the FRAP assay. Anal Biochem 293:70-76

Chay Pak Ting BP, Mine Y, Juneja LR, Okubo T, Gauthier SF, Pouliot Y (2011) Comparative composition and antioxidant activity of peptide fractions obtained by ultrafiltration of egg yolk protein enzymatic hydrolysis. Membranes 1:149-161

Chi C-F, Hu F-Y, Wang B, Li Z-R, Luo H-Y (2015) Influence of amiono- acid compositions and peptide profiles on antioxidant capacities of two protein hydrolysates from Skipjack tuna (Katsuwonus peoamis) dark muscle. Mar Drugs 13(5):2580-2601

Chrzanowska J, Kołaczkowska M (1998) Production of extracellular proteolytic enzymes by Beauveria bassiana. Acta Mycol 33:277-285

Davalõs A, Miguel M, Bartolome B, López-Fandiňo R (2004) Antioxidant activity of peptides derived from egg white proteins by enzymatic hydrolysis. J Food Prot 67:1939-1944

Duan X, Zhou Y, Li M, Wu F, Yang N, Xu J, Chen H, Jin Z, Xu X (2014) Postfertilization changes in conformation of egg yolk phosvitin and biological activities of phosphopeptides. Food Res Int 62:1008-1014

Eckert E, Zambrowicz A, Pokora M, Setner B, Dąbrowska A, Szołtysik M, Szewczuk Z, Polanowski A, Trziszka T, Chrzanowska J (2014) Egg-yolk protein by-product as a source of ACE inhibitory peptides obtained with using unconventional proteinase from asian pumpkin (Cucurbita ficifolia). J Prot 110:107-116

Eckert E, Lu L, Unsworth LD, Chen L, Xie J, Xu R (2016) Biophysical and in vitro absorption studies of iron chelating peptide from barley proteins. J Funct Foods 25:291-301

Feng F, Mine Y (2006) Phosvitin phosphopeptides increase iron uptake in a Caco-2 cell monolayer model. Int J Food Sci Technol 41:455-458

Hernández-Ledesma B, Recio I, Amigo L (2008) Beta-lactoglobulin as source of bioactive peptides. Amino Acids 35(2):257-265

Ishikawa S, Yano Y, Arihara K, Itoh M (2004) Egg yolk phosvitin inhibits hydroxyl radical formation from Fenton reaction. Biosci Biotechnol Biochem 68:1324-1331

Ishikawa S, Asano T, Takenoshita S, Nozawa Y, Arihara K, Itoh M (2009) Egg yolk proteins suppress azoxymethane-induced aberrant crypt foci formation and cell proliferation in the colon of rats. Nutr Res 29:64-69

Jiang B, Mine Y (2000) Preparation of novel functional oligophosphopeptides from hen egg yolk phosvitin. J Agric Food Chem 48:990-994

Katayama S, Xu X, Fan MZ, Mine Y (2006) Antioxidative stress activity of oligophosphopeptides derived from hen egg yolk phosvitin in Caco-2 cells. J Agric Food Chem 54:773-778

Katayama S, Ishikawa S, Fan MZ, Mine Y (2007) Oligophosphopeptides derived from egg yolk phosvitin up-regulate gamma-glutamylcysteine synthetase and antioxidant enzymes against oxidative stress in Caco- 2 cells. J Agric Food Chem 55(28):29-35

Kim HK, Lee S, Leem KH (2010) Protective effect of egg yolk peptide on bone metabolism. J Agric Food Chem 58:7624-7633

Kozłowski H, Mangani S, Messori L, Orioli PL, Scozzafava A (1988) $\mathrm{CD}$ and EXAFS study of the interaction between phosvitin and copper(II) ions. J Inorg Biochem 34:221-239

Kuchroo CN, Ramilly J, Fox PF (1983) Assessment of proteolysis in cheese of reaction with trinitrobenzene sulphonic-acid. Irish J Food Sci Technol 7:129-133

Lee SY, Hur SJ (2017) Antihypertensive peptides from animal products, marine organisms, and plants. Food Chem 228:506-517

Lemieszewska M, Jakubik-Witkowska M, Stańczykiewicz B, Zambrowicz A, Zabłocka A, Polanowski A, Trziszka T, Rymaszewska J (2016) Pro-cognitive properties of the immunomodulatory polypeptide complex, yolkin, from chicken egg yolk and colostrum- derived substances: analyses based on animal model of age- related cognitive deficits. Arch Immunol Ther Exp (Warsz) 64(5):425-434

Lesnierowski G, Stangierski J (2018) What's new in chicken egg research and technology for human health promotion?-a review. Trends Food Sci Technol 71:46-51

Liu C, Fang L, Min W, Liu J, Lia H (2018) Exploration of the molecular interactions between angiotensin-I-converting enzyme (ACE) and the inhibitory peptides derived from hazelnut (Corylus heterophylla Fisch.). Food Chem 245:471-480

Lowry OH, Rosebrough NJ, Farr AL, Randal RJ (1951) Protein measurement with the Folin-phenol reagent. J Biol Chem 193:265-275

Lu J, Sawano Y, Miyakawa T, Xue YL, Cai MY, Egashira Y, Ren DF, Tanokura M (2010) One-week antihypertensive effect of IleGln-Pro in spontaneously hypertensive rats. J Agric Food Chem 59:559-563

Memarpoor-Yazdi M, Mahaki H, Zare-Zardini H (2013) Antioxidant activity of protein hydrolysates and purified peptides from Ziziphus jujuba fruits. J Funct Foods 5(1):62-70

Miguel M, Recio I, Gomez-Ruiz JA, Ramos M, Lopez-Fandino R (2004) Angiotensin I- converting enzyme inhibitory activity of peptides derived from egg white proteins by en-zymatic hydrolysis. J Food Prot 67:1914-1920

Pokora M, Eckert E, Zambrowicz A, Bobak Ł, Szołtysik M, Dąbrowska A, Chrzanowska J, Polanowski A, Trziszka T (2013) Biological and functional properties of proteolytic enzyme modified egg protein by-products. Food Sci Nutr 1(2):184-195

Polanowski A, Zabłocka A, Sosnowska A, Janusz M, Trziszka T (2013) Immunologically active peptides that accompany hen egg yolk IgY- separation and identification. Biol Chem 394(7):879-887

Shade R, Chacana PA (2007) Livetin fractions (IgY). In: Huopalahti R, López-Fandiño R, Anton M, Schade R (eds) Bioactive egg compounds. Springer, Berlin, pp 25-32

Siepka E, Bobak Ł, Trziszka T (2010) Frakcjonowanie żółtka w celu pozyskiwania preparatów wzbogaconych w substancje biologicznie aktywne. ZTNJ 6(73):158-167 (in Polish).

Silvestre MPC (1996) Review of methods for the analysis of protein hydrolysates. Food Chem 60:263-271

Wu JP, Aluko RE, Nakai S (2006) Structural requirements of angiotensin I- converting enzyme inhibitory peptides: quantitative structure-activity relationship modeling of peptides containing 4-10 amino acid residues. Qsar Comb Sci 25(10):873-880

Wu R-B, Wu C-L, Liu D, Yang X-H, Huang J-F, Zhang J, Liao B, He H-L (2018) Antioxidant and anti-freezing peptides from salmon collagen hydrolysate prepared by bacterial extracellular protease. Food Chem 248:346-352

Xu X, Katayama S, Mine Y (2007) Antioxidant activity of tryptic digests of hen egg yolk phosvitin. J Sci Food Agric 87:2604-2608 
Yen GC, Chen HY (1995) Antioxidant activity of various tea extracts in relation to their antimutagenicity. J Agric Food Chem 43:27-32

Yoshii H, Tachi N, Ohba R, Sakamura O, Takeyama H, Itani T (2001) Antihypertensive effect of ACE inhibitory oligopeptides from chicken egg yolks. Comp Biochem Physiol C 128:27-33

Yousr M, Howell N (2015) Antioxidant and ACE inhibitory bioactive peptides purified from egg yolk proteins. Int J Mol Sci 16:29161-29178

Yousr MN, Aloqbi AA, Omar UM, Howell NK (2017) Antiproliferative activity of egg yolk peptides in human colon cancer cells. Nutr Cancer. https://doi.org/10.1080/01635581.2017.1295087

Yu Z, Yin Y, Zhao W, Chen F, Li J (2018) Application and bioactive properties of proteins and peptides derived from hen eggs: opportunities and challenges. J Sci Food Agric 94(14):2839-2845

Zabłocka A, Zambrowicz A, Macała J, Kazana W, Polanowski A (2018) Yolkin-a polypeptide complex isolated from chicken egg yolk with potential neuroprotective and antioxidative activity.
Neuropsychiatry (London). https://doi.org/10.4172/Neuropsych iatry. 1000502

Zambrowicz A, Eckert E, Pokora M, Bobak Ł, Dąbrowska A, Szołtysik M, Trziszka T, Chrzanowska J (2015a) Antioxidant and antidiabetic activities of peptides isolated from an egg-yolk protein by-product hydrolysate prepared with the use of proteinase from Asian pumpkin (Cucurbita ficifolia). RSC Adv 5:10460-10467

Zambrowicz A, Pokora M, Setner B, Dąbrowska A, Szołtysik M, Babij K, Szewczuk Z, Trziszka T. Lubec G, Chrzanowska J (2015b) Multifunctional peptides derived from an egg-yolk protein byproduct hydrolysate: isolation and characterization. Amino Acids 47(2):369-380

Zambrowicz A, Zabłocka A, Sudoł M, Bobak Ł, Sosicka P, Trziszka T (2018) The effect of carbohydrate moieties on immunoregulatory activity of yolkin polypeptides naturally occurring in egg yolk. LWT- Food Sci Technol 88:165-173 